\title{
The European Management Forum - A Non-State Actor and the European Community
}

\section{Claudia Hiepel}

At the invitation of Swiss-German Corporate Policy Professor Klaus Schwab, several hundred top managers, members of the EU Commission and economists gathered in January 1971 in the small, remote, sophisticated Swiss skiing resort of Davos, for a fourteen-day meeting. The purpose of the event was to acquaint European economic players with modern American economic methods and to develop new company strategies for Europe. This European Management Symposium heralded the start of a series of yearly meetings and the formation of a charitable trust fund which first went by the name of the European Management Forum (EMF) and continued, from 1987 onwards, as the World Economic Forum (WEF). Today, the WEF and the meetings in Davos are considered one of the most prestigious, albeit controversial, platforms of global elites in the world of economics and politics. At the meeting in January 2012, 2600 delegates came together under the ubiquitous and watchful eye of the mass media; among these delegates 40 government leaders alone were to gather under the motto "The Great Transformation - Shaping New Models" and to reflect on the best ways of dealing with global problems. ${ }^{1}$

From modest beginnings in 1971, the meeting in Davos has now developed into an outstanding major event. The value of its importance ranges from being ranked hugely influential in creating a standardised view of modern capitalism or it is trivialised and called nothing more than one big cocktail party producing barely tangible results. ${ }^{2}$ In the last decade it has increasingly been in the focus of a growing movement critical of globalisa-

1 Hannes Koch, "Kapitalismus renovieren. Weltwirtschaftsforum von Davos" in Die Tageszeitung, 24.1.2012.

2 The first view held by globalisation critic Ignacio Ramonet, the second view by the philantropist and hedgefonds manager Georges Soros, both mentioned in: Jean Christophe Graz, "How Powerful are Transnational Elite Clubs? The Social Myth of the World Economic Forum" in New Political Economy, 8, 3, 2003, pp. 321-340, here: p. 321 . 
tion whilst involving less militant representatives of this movement within its ranks. ${ }^{3}$

Two opposed narratives can be distinguished which American political scientist Geoffrey Allen Pigman describes by the metaphor of "Shar-Pei" and the "wolf in sheep's clothing". Just as the Chinese folding dog develops out of a little puppy with an excess of folds and fur into a well-proportioned, fully grown dog, the EMF/WEF has made a step-by-step development towards being an influential, transnational organisation. " ${ }^{4}$ Committed to improve the state of the world" - this has been the immodest, official motto since 1987. In this context, the WEF is committed to concentrating power from all nations in a globalised world in order to benefit everybody. ${ }^{5}$

The second narrative describes the WEF as a "wolf in sheep's clothing", as it seems to hide, behind its do-gooder rhetoric, an attitude which conceals the desire to promote the interests of transnational companies and leading industrial nations and push through their version of global capitalism at the expense of environmental and social standards. ${ }^{6}$ For these reasons, a pejoratively tinged expression such as the "Davos man" was used for people who "have little need for national loyalty, view national boundaries as obstacles that thankfully are vanishing, and see national governments as residues from the past whose only useful function is to facilitate the élite's global operations." The British historian Timothy Garton Ash perceived a "dominant culture of Davos [that] remains that of white western man." According to him, the Davos man is "mainly white, middle-aged and European or AngloSaxon."

3 In January 2012, for instance, the gathering had to be closed off by 5000 Swiss soldiers to be protected against its critics. In contrast the observations of Josef.Joffe, "Dreimal Davos. Das Weltwirtschaftsforum hat drei Bühnen" in Die Zeit, 27.1.2010.

4 Geoffrey Allen Pigman, "A Multifunctional Case Study for Teaching International Political Economy: The World Economic Forum as Shar-pei or Wolf in Sheep's Clothing?" in International Studies Perspectives, 2, 2002, pp. 291-309, here: p. 294.

5 On the history of the WEF from the beginnings to date, historical research can only draw on the official history of the forum that is based on the analysis of internal documents: The World Economic Forum. A Partner in Shaping History. The First 40 Years, Colgny/Geneva 2009.

6 On the opponents and their organisational forms see Geoffrey Allen Pigman, The World Economic Fonim. A multi-stakeholder approach to global governance, New York: Routledge, 2007, pp. 123ff.

7 Samuel Huntington, "Dead Souls: The Denationalization of the American Elite" in The National Interest, 75, 2004, pp. 5-18.

8 Timothy Garton Ash, "Davos man's death wish" in The Guardian, 3.2.2005. 
much more than accessories. For American sociologist Richard Sennet, the "homo davosiensis" represents an archetype of modern managerial elites, a core group of about 1000 globally acting high achievers. ${ }^{9}$

The WEF is therefore in the focus of a broad societal debate on the problems of global capitalism and its effects on European societies. But how really important is this elusive organisation in this discourse and in the process of globalisation itself? As (according to its own statements) an independent non-profit organisation which finances itself through the donations of its members and large multinational concerns, it carries out "high-levelnetworking" in the world of economics, politics and amongst players in civil society. ${ }^{10}$ It defines itself as an interface between such diverse players, in order to make possible and help to develop a broad global discourse. We cannot deny the fact that this forum must have a considerable influence on matters, but where exactly this influence comes into play and how we can measure it in concrete terms is far more difficult to ascertain precisely.

It is indeed in the nature of things that it is difficult to prove the influence of networks on political decision-making. There are two reasons for this: firstly, the confidential nature of the forums themselves and, secondly, the lack of written sources. The meeting in Davos is, of course, no longer a clandestine event; the organisers themselves are part of a broadly staged media event. ${ }^{11}$ The influence of this event on the public debate can be determined by the existence of published sources. This was not quite the case when the organisation was in its formative days: a wider public interest only developed in the second half of the Eighties. And even then, numerous subforums and confidential discussion groups have developed in the wings which further hamper chances of transparency.

Although the problem of sources makes historical research on networks and semi-private organisations more difficult, they have, however, become an important topic when relating international history. Since the transformation of statehood in and through Europe and on the global level since the Nineties, networks and NGOs have an important role to play. "Governing" is no longer a "privilege" of state players. The European Management forum

9 Richard Sennet, "The dizzy life of Davos man" in The Independent, 11.10.1998.

10 The World Economic Forum. A Partner in Shaping History, p. 166. Amongst the early members were corporations such as Royal Dutch Shell, Unilever or Philips. See also the list of "strategic partners" in 2009 , ibd., p. 253.

11 On the manifold activities and involvements see the website of the organisation: www.weforum.org. 
is therefore a suitable test case for governing within a multi-level system. ${ }^{12}$ European research on integration has discovered the influence of networks; initial research on comparable organisations such as the Bilderberg Group $^{13}$ or the European Round Table of Industrialists ${ }^{14}$ has already been carried out. On the other hand, the EMF/WEF has so far not been the subject of historical research. ${ }^{15}$ This might be astonishing, as the Davos "success story" is closely linked to Europeanisation and globalisation. They both started in the Seventies, that were characterised by a rapid growth of multinational corporations and international NGOs. ${ }^{16}$ The WEF evolved most impressively in the $1990 \mathrm{~s}$ and in the first decade of the $21^{\text {st }}$ century, when the resolution of the Cold War gave way to the accelerated development of a new world order and the victory of a liberal capitalist economic order ${ }^{17}$ with which the Forum is frequently identified.

12 Gary Marks/ Liesbet Hooghe/ Kermit Blank, "European Integration from the 1980s: State-Centric vs. Multi-level Governance" in Journal of Common Market Studies, 34, 1996, pp. 341-378. A similar reading of the WEF as a new form of global governance in Geoffrey Allen Pigman, The World Economic Forum. A multi-stakeholder approach to global governance, New York: Routledge, 2006.

13 Valérie Aubourg, "Transatlantische Geschäftsbeziehungen. Die BilderbergGruppe”, in: Michael Gehler/ Wolfram Kaiser /Brigitte Leucht (eds.), Netzwerke im europäischen Mehrebenensystem. Von 1945 bis zur Gegenwart, Wien: Böhlau, 2009, pp. 69-85.

14 Maria Green Cowles, The European Round Table of Industrialists and the Single Market Program. From Political to Policy Network, in: ibd., pp. 139-150.

15 Besides infrequent mentioning of the „Davos man“" in literature, only political sciences have dealt with the WEF more systematically yet. Rather affirmative Pigman, The World Economic Forum. A multi-stakeholder approach to global governance; hypercritical Graz, How Powerful are Transnational Elite Clubs? This Swiss political scientist reports on the enormous difficulties to get access to sources and contemporary witnesses.

16 Akira Iriye, Global Community. The Role of International Organizations in the Making of the Contemporary World, Berkeley: University of California Press, 2002; idem, "Nationale Geschichte, Internationale Geschichte, Globale Geschichte", in: Manfred Berg/ Philipp Gassert (eds.), Deutschland und die USA in der Internationalen Geschichte des 20. Jahrhunderts. Festschrift fïr Detlev Junker, Stuttgart: Franz Steiner Verlag, 2004, pp. 21-39.

17 Volker Berghahn sees a "watershed of two eras". Volker R. Berghahn, "Structuralism and biography. Some Concluding Thoughts on the Uncertainties of a Historiographical Genre", in: Idem/ Simone Lässig (eds.), Biography between Structure and Agency. Central European Lives in International Historiography, New York/ Oxford: Berghahn Books, 2008, pp. 234-250, here: p. 241. 
Originally, the symposia Klaus Schwab had been organising in Davos since 1971 were conceived as a European answer to the onset of globalisation. Even if the term "Globalisation" was not yet in regular use at the beginning of the Seventies, the accelerated processes connected to growing transnational interdependencies were certainly evident. Even though, in hindsight the Seventies can generally be seen as a "turning point", coming hand in hand with an increasing number of political, economic, scientific, technological, social, cultural or mental transformations ${ }^{18}$, observers at the time realised that we were living in an epoch of upheaval without yet having found a term to describe it. Louis Armand, the first head of Euratom, described it as an epoch of "planetisation". The new view of Earth, as well as space research which had made the first trips to the moon possible, opened up whole new perspectives on the planet which now seemed small and unimportant and on which the drawing up of borders now seemed arbitrary. 19

The problems linked to planetisation at the turn from the Sixties to the Seventies were, however, far more prosaic and were popularised under the slogan of "the American challenge". This had its origins in the provocative essay by left-wing intellectual French journalist Jean-Jacques ServanSchreiber which was published under the title "Le défi américain" and was reprinted and translated many times in the following years. Servan-Schreiber made clear the widespread concern of the Europeans that European companies would be sold out to Americans, leading to an American conquest of the market through direct investments. ${ }^{20} \mathrm{He}$ identified the "technological gap" as the cause of American domination as well as a "managerial gap"

18 Robert Cox, "Globalization, Multilateralism and Democracy", in: Idem/ T. Sinclair, Approaches to World Order, Cambridge: Cambridge University Press, 1996, pp. 524-536. From a historical perspective see Madeleine Herren, Internationale Organisationen seit 1865. Eine Globalgeschichte der internationalen Ordnung, Darmstadt: Wissenschaftliche Buchgesellschaft, 2009, pp. $3 \mathrm{fb}$, who regards globalisation as a "tief in die Geschichte hineinreichende[n] Normalfall", not strictly confined to contemporary history.

19 Louis Armand, in: Jean-Jacques Servan-Schreiber, Die amerikanische Herausforderung, Hamburg: Hoffmann und Campe, 1968, pp. 359-367.

20 Jean-Jacques Servan-Schreiber, Le défi américain, Paris: Denoël, 1967. The German translation appeared in 1968: Die amerikanische Herausforderung, with a foreword written by the Bavarian Christian Socialist party leader Franz-Josef Strauß! On the reception in Germany and France see the critique of Gerhard Stoltenberg in Der Spiegel, 11/1968, pp. 154-157 sowie Mario Levi in Politique étrangère, 33, no. 6, 1968, pp. 644-647. 
between Europe and the USA. The USA had not only risen to become the leading nation in the fields of future technologies such as nuclear power, electronics, space research and electronic data processing but was now leading the way in the application of rational management techniques and methods. ${ }^{21}$

Klaus Schwab, who was obviously impressed by this bestseller, wanted to make his own contribution towards "bridging the management gap between the USA and Europe". ${ }^{22}$ If we look at the founding history of the EMF, this is primarily the product of the commitment of one single person. Born in the Swabian town of Ravensburg in 1938, having grown up in the SwissGerman border region, Schwab had already been a champion of international understanding and Franco-German youth exchange programs during his youth. He obtained a Doctorate in Mechanical Engineering and Economic Sciences, studied for a year, from 1966 to 1967, at the University of Harvard (Kennedy School of Government) and also attended courses at the renowned Harvard Business School at the same time. He met numerous influential personalities there who were later to become regular guests at the symposia. In 1970 he then began preparations for the first European Management Forum, intending "to bring European corporate managers together with their stakeholders". ${ }^{23}$ In this context he wanted to transfer the insights he had gained in the USA to Europe and convince European managers of the stakeholder approach. In 1971 he published a short book in which he took the example of mechanical engineering to explain the obviously unfamiliar Stakeholder Theory in which successful, modern business leadership is not supposed to be limited to the maximisation of profit but is also supposed to consider the interests of everybody involved in the production flow and distribution process: this would also include, along with the owner and shareholders, the customers, suppliers, the employees as well as the governments, society's interest groups and the national economies. ${ }^{24}$ The business principle of multi-stakeholder participation was also transmitted to the organi-

21 Servan-Schreiber, Die amerikanische Herausforderung, p. 56.

22 Lange gerudert in Der Spiegel no. 4, 1988, pp. 71-74, hier: p. 74; Joachim Dorfs/ Claus Larass, "'Ich sehe mich fast als Künstler.' Der Davos-Gründer Klaus Schwab", in: Bernd Ziesemer (ed.), Pioniere der deutschen Wirtschaft. Was wir von den großen Unternehmerpersönlichkeiten lernen können, Frankfurt/ New York: Hoffmann und Campe, 2012, pp. 113-124, here: p. 115.

23 The World Economic Forum. A partner in shaping history, p. 7.

24 Klaus Schwab, Moderne Unternehmensfïhrung im Maschinenbau, Frankfurt: Maschinenbau-Verlag, 1971. 
sation itself which was attempting to bring together stakeholders from industry, the European Union and its member states, trade unions and other playmakers from civil society.

After the successful start to the inaugural meeting, Schwab decided to use the profits he had made from the first symposium to found a non-profit trust: the European Management Forum was born. The fact that Schwab benefitted from contacts made in the setting up of his forum and thanks to his position as a member of the "Centre d'Études Industrielles (CEI)" in Geneva is not mentioned in the company's official view of events. The CEI had already been set up as a Management School in 1946, where Klaus Schwab had already been teaching and which was one of the most influential schools of its type. The Symposium in 1971 was a commemorative event which Schwab set up to celebrate the $25^{\text {th }}$ anniversary of the CEI. ${ }^{25}$ That hardly diminishes Schwab's role as an individual protagonist, however. ${ }^{26}$

From the very beginning, the EC Commission was concerned as a stakeholder in planning and execution. The gap that Servan-Schreiber identified as an industrial gap to the USA could only be filled with the help of improved conditions in Europe. A uniform industrial policy in the EEC did, however, not exist. The Treaties of Rome did not plan any concrete measures to this end. Industrial policy was restricted to coordinating the economic policies of individual member states and ensuring that competition rules were being adhered to. ${ }^{27}$ In this respect the USA were regarded as being exemplary in the way in which they effectively employed a policy of "cross-fertilisation", by using public funding for research and science and applying it in industrial companies. ${ }^{28}$ Since 1970 , however, there had been a politically strong EC

25 Jean-Christophe Graz, "How Powerful are Transnational Elite Clubs?" in New Political Economy, 8, 2003, pp. 328-330, whose observations are based on archival sources of the CEI that can be found in the university's archive of Geneva.

26 Contrary to Graz, ibid., p. $328 \mathrm{f}$. on the importance and the programme of the CEI see: Rosemarie Fiedler-Winter, Die Management-Schulen, Düsseldorf/Wien: EconVerlag 1973, pp. 197-200.

27 Eric Bussière, "Schwierige Anfänge einer Industriepolitik" in: Die Europäische Kommission 1958-1972. Geschichte und Erinnerung einer Institution, Luxemburg: Amt für Amtl. Veröff. der Europ. Gemeinschaften 2007, pp. 489-503; Idem, "D'une Europe inachevée à l'affirmation du regionalism européen dans la mondialisation", in: Antonio Varsori/ Guia Migani (eds.), Europe in the International Arena during the 1970s. Entering a Different World, Brüssel: Peter Lang, 2011, pp. 41-54. It was finally the Maastricht Treaty in 1992 that modified the EC Treaty in order to provide a legal basis for a common industrial policy (art. 157).

28 Servan-Schreiber, Die amerikanische Herausforderung, p. 56. 
Commissioner in the form of the Italian Federalist, Altiero Spinelli, who had a particularly strong desire to shape the Community's industrial policy. ${ }^{29} \mathrm{He}$ envisaged corporate ideas of industrial planning by involving all interest groups: the European Community, the member states, trade unions and economic leaders - this clearly corresponded to the concept of Klaus Schwab. He therefore had an easy job when trying to get the Commission involved. The Commission's president assured him of his support, although he attached two conditions: firstly, the organisation they planned was to be independent and non-profit making and, secondly, meetings were to be held in a country of the European Community. This clearly was not the case with Davos, which was in Switzerland. ${ }^{30}$ However, this did not prevent the Commission from taking part in the meeting with high-ranking delegates. The Vice President of the Commission, Raymond Barre, acting as Commissioner for both Finances and Economy, as well as Spinelli, took part in the first meeting and took on the patronage in the first few years.

"Developing a European Corporate Strategy" - this motto, as one of the first symposia, refers to the European focus in the early years of the Forum. The Chair was taken by the US economist George P. Baker, Dean of the renowned Harvard Business School. John Kenneth Galbraith, liberal US economist and consultant for a number of Democratic Presidents, acted as a Keynote Speaker. Hermann Kahn, on the other hand, a highly controversial figure of American Conservatism, a frequent consultant in various conservative Think Tanks, was also present. A broad spectrum of opinions was to be represented and this was to be, according to the wishes of the initiators, a key characteristic of the Forum and back up the myth of the "Davos Spirit": the climate should be one of unprejudiced intellectual exchange based on vastly differing opinions and should encourage the cross-fertilisation of

29 Sigfrido M. Ramírez Pérez, "Transnational business networks propagating EC industrial policy: The role of the Committee of Common Market Automobile Constructors", in: Wolfram Kaiser/ Brigitte Leucht/ Morten Rasmussen (eds.), The History of the European Union. Origins of a trans-and supranational polity 1950-72, New York: Routledge, 2009, pp. 74-92, here: p. 78. DG III for industrial policy had not been installed before 1967. On the industrial policy after Spinelli's withdrawal in 1976 see Arthe van Laer, "Quelle politique industrielle pour l'Europe? Les projets des Commissions Jenkins et Thorn (1977-1984)", in: Milieux économiques et intégration européenne au XXe siècle. La relance des années quatre-vingt (19791982), Paris, 2007, pp. 7-52.

30 The World Economic Forum. Partner in Shaping History, p. $13 \mathrm{ff}$. 
ideas. ${ }^{31} \mathrm{~A}$ broad range of topics was developed which moved away from, strictly speaking, management topics and more towards larger debates on society and topical problems. In addition, the American model was rapidly losing esteem. Being ahead in the technical and entrepreneurial sense had not prevented the American trade deficit and the fall of the Dollar, which had brought about a currency crisis and a monetary paradigm shift. ${ }^{32}$ The EMF reacted immediately, by making the currency crisis and possible solutions a subject at the European level in 1972 under the leadership of the head of the Deutsche Bank, Hermann Josef Abs. The Prime Minister of Luxembourg, Pierre Werner, presented the results of a working group named after and led by him and set up by the Council of Ministers to develop a plan by stages to create an economic and currency union. The setting up of a common European economic and currency union was regarded by participants as a pre-condition for effective trade; the idea of extending EU membership to include Great Britain, Ireland, Denmark and Norway in this European economic area was also welcomed.

In 1973, together with Aurelio Pecci, the co-founder and President of the Club of Rome, the recently published study entitled "The limits to growth" on the future of the world economy was discussed..$^{33}$ Influenced by the gloomy prognoses proffered in the report, the participants of the Forum decided on a code of ethics, the so-called Davos Manifesto, in which the idea was put forward that the profitability of a company should be linked to moral and ethical standards in business. Based on the stakeholder approach, responsible company management aims to serve customers, investors and employees equally and, bearing in mind what the Davos meeting had just have heard, to use resources sparingly: "The management has to serve society. It must assume the role of a trustee of the material universe for future generations." The payment of "appropriate taxes" was an obligation of companies,

31 Ibid., p. 7.

32 The decision of US president Richard Nixon in august 1971 to unilaterally terminating the convertibility of the dollar into gold was the beginning of the end of the international currency system of Bretton Woods, Harold James, Rambouillet, 15. November 1975. Die Globalisierung der Wirtschaft, München: DTV, 1997, pp. $131 \mathrm{ff}$.

33 Donella H. Meadows et. al, The Limits to Growth. A report for the Club of Rome's project on the predicament of mankind, New York: Universe Books, 1972. 
so that state and society can finance the tasks they have to provide. ${ }^{34}$ The "Davos man" at this time had the reputation of being an upholder of moral standards rather than being an irresponsible global player. ${ }^{35}$

A further remit of the Forum was to invite high-profile critics of the current economic and social order. There was a wide range of people involved, such as the French environmental protectionist, Jacques Cousteau (1973), who had become famous as a result of his TV documentaries, the theologian, Dom Helder Camara, in the following year, environmental campaigners like Ralph Nader in 1976 or the German peace campaigner and co-founder of the German Green Party, Petra Kelly, in 1982. ${ }^{36}$

Just as the meetings in Davos were a springboard for the mission statement of the EMF, informal discussions then took place in different forums, round table talks and meetings. As early as 1973 two series of round table talks were set up, one of them in Brussels between the European business representatives and the Commission, and one in Bonn to discuss German industrial policy. These talks were gradually extended and introduced in further European Countries. ${ }^{37}$ In 1982 the IGWEL (Informal Gathering of World Economic Leaders) was established as an informal circle of leading business and politics representatives which made "off the record" conversations possible. Clearly, such round tables and informal conversations were a good opportunity for people to get together with different conversation partners in unusual constellations outside the usual business and political circles without the pressure of having to produce concrete results. At the same time there was the criticism that precisely these types of forums lacked transparency and democratic legitimacy. It is very difficult to ascertain which results were obtained through these meetings. The idea resulting in NAFTA,

34 "Code of Ethics - The Davos Manifesto", in: Rosemarie Fiedler-Winter, Die Moral der Manager, Stuttgart: Seewald Verlag, 1977; also published in The World Economic Forum. Partner in Shaping History, p. 16.

35 Rosemarie Fiedler-Winter, "Die Moralapostel von Davos. Für die Fühnungskräfte der Wirtschaft wird ein Verhaltenskodex entwickelt" in Die Zeit, 26.4.1974.

36 All examples in The World Economic Forum. Partner in Shaping History.

37 tbid., p. 17. 
the North American Free Trade Arrangement, was supposed to have been born there. ${ }^{38}$

The EMF very soon left the concept regarding Europe and Transatlantic transfer ofideas behind. It reached out its feelers in the economic areas outside Europe shortly after its formation. In 1976 Arab and European economic representatives came together on the initiative of the EMF in Montreux, to form an Arab-European Business Co-operation Symposium in an attempt to relax tension in the relationship between the Arab world and the Western industrial nations after the oil crisis of 1973/74. In 1979 Schwab was also fascinated by the new course in China as laid down by the new Chinese leader, Deng Xiao Ping, and also sent out an invitation to him; of course he did not appear personally but at least sent a delegation to Davos. ${ }^{39}$ Finally, the historic meeting in 1986 between the Greek and Turkish Prime Ministers, Andreas Papandreou and Turgut Özal, needs to be mentioned, as they managed to make a shake-hands appearance on a panel in Davos. This did not mean that the problem of Cyprus had been solved, but a contribution to an improvement in the climate between the two states had been made. At the same meeting in 1986, just before the fall of the Iron Curtain, the Soviet Prime Minister, Nikola Ryzhkov, was represented via satellite. ${ }^{40}$

During the 1970s the Davos European Management Forum had firmly been established as a non-governmental organisation. The attendance increased to about 900 participants, among them the leaders of large European companies such as Royal Dutch Shell, Unilever or Philips. First official cooperations with other international organisations, the UNIDO (United Nations Industrial Development Organisation) for instance, were established. Soon the OECD joined as official sponsor and host of some of the round tables that were established in European capitals and by the Commission in Brussels to create national fora under the EMF organisational umbrella. The Davos meetings were generally characterised by a politicisation concerning the issues as well as the invited guest speakers. High-ranking political leaders

38 Ibid., p. 56. According to that, in 1984 on the part of the EC there were present Raymond Barre, Piet Dankert (EC parliament's president) and Leslie Fielding (DG for external relations), also the President of the Worldbank, GATT representatives, the Secretary General of the OECD, German Minister of Economics Graf Lambsdorff, members of the governments of Brazil, Malaysia, Australia, Zimbabwe and the Director General of the ILO. The role and presence of corporate managers is not mentioned here.

39 The World Economic Forum. A Partner in Shaping History, p. $29 \mathrm{ff}$.

40 Ibid., pp. 63-70. 
were now regularly invited, beginning with Valéry Giscard d'Estaing, Helmut Schmidt or opposition leaders and potential future heads of state, such as Mitterrand in 1976. During the 1980s the EMF then developed into an important event that was attended regularly by business leaders of international firms under the participation of representatives of all stakeholders in a globalising economy: government officials, leaders of multilateral organisations such as the World Bank, IMF or GATT. It was Henry Kissinger who got to the heart of the transformative process when asserting in a speech at the 1980 Davos meeting that "for the first time in history, foreign policy is truly global", ${ }^{41}$ as the classical nation-states were on the way of losing economic autarky and had to face the appearance of new challenges (environment, security, developing countries) that affected all of humanity.

This marked the definite shift of the EMF to the global sphere of action. Did that mean that the European problems were "solved"? Far away from that, at least the pessimistic if not alarmist analysis of the early 1970 s that saw European economy in an accelerating decline in comparison to the US turned out to be wrong. Europe had succeeded with becoming more competitive globally. Furthermore, globalisation gained ground in a way that probably was not expected in the early 70 s regarding its rapidness and scope, which necessarily soon lead to broadening the field of action. Initially a European forum that put out feelers to the US, the EMF underwent a development into an organisation that tried to assert influence on global economic, political and even security matters. Consequently, Schwab changed the name of the Forum in World Economic Forum in 1987.

Finally, the question remains what lessons can be learned for a new international history by examining the EMF. ${ }^{42}$ First of all, the history of the EMF/WEF properly serves as an example of a new approach in international history, as it is a type of international organisation that is unlike other multilateral economic institutions such as IMF, World Bank, WTO or the G 7/8 summits. The EMF was not intended to be a public international organisation. Right from the beginning it had the form of a private, non-profit foundation with the aim to promote the exchange of information and ideas. It was self-selecting and decided whom to admit. The financial basis was laid by

41 Opening address by Henry Kissinger, ibid., p. 36.

42 On the potential of a "new international history" see the contributions in Studies in Contemporary History, 8, 2011, H. 3, "International Orders and New Universalisms in the Twentieth Century" [www.zeithistorische-forschungen.de], 4.12.2013. 
the membership fee of the European and later on global firms and the fees paid by the attendees of the annual meeting.

The EMF/WEF can be characterised as an organisation whose members were non-governmental, indeed it is nonetheless a venue and platform for diplomacy. Whereas foreign affairs traditionally have been a field of government to government interaction about security, defense or resources, the agenda of contemporary diplomacy comprises economic, social and cultural issues for which NGOs and global firms or civil society act instead of or in addition to state governments. In the concept of a multi-track diplomacy, the EMF would represent track-II (NGOs) and track-III (business, peacemaking through commerce) diplomacy. ${ }^{43}$ Klaus Schwab pursued his own policy of détente, basing on the conviction that there exists a close interconnection between diplomacy, security and business climate.

EMF/WEF history would serve as a perfect example of network analysis in international history. ${ }^{44}$ Klaus Schwab as a network-performer ${ }^{45}$ played a crucial role in bringing people together that normally would not have met and to create settings to facilitate making contacts. Tracing the structure of Klaus Schwab's ego-network and the networks of other regularly participating people would allow us to better understand how ideas and economic ideologies could have been communicated globally.

EMF/WEF history is also about the influence of discourses in international history. Discourses were (and are) at the core of the Davos meetings, and at the same time Davos had an effect on discourses. It promoted a version of globalisation that was revolving around market opening and liberalisation. The EMF/WEF is a product of globalisation and a driving force at the same time. The idea of a new round of GATT deliberations, the Uruguay round in 1986 that lead to the creation of WTO in 1995 as the successor of GATT is said to have been developed in the informal gatherings during the Davos

43 See for that Louise Diamond/John W. McDonald, Multi-track diplomacy: a systems approach to peace, West Hartford: Kumarian Press, 1996. The authors identify and examine nine tracks of the multi-track diplomacy system: government/professional conflict resolution by NGOs/business private citizen/research, training and education/activism/religion/funding/public opinion, media.

44 Michael Gehler/ Wolfram Kaiser/ Brigitte Leucht, "Networks in Informal European Governance. Diachronic Perspectives on the European Union as a Multi-Level Polity", in: Idem (ed.), Networks in European Multi-Level Governance. From 1945 to the Present, Wien: Böhlau, 2009, pp. 9-25.

45 Michael Machatschke, "Klaus Schwab. Der Netzkünstler" in Manager Magazin, 30.7 .2007 . 
meetings. The IGWEL (Informal Gathering of World Economic Leaders) was a forum, established in 1982, where economic leaders could meet politicians still more off-the record, more informal than at the normal Davos gatherings. Those meetings aimed at informal consensus-building and were catalysts for launching new ideas.

Davos is, last but not least, a history of processes of economic transfer from the US to Europe and, as a result, the rapprochement of European and US economic model. The dominant version of globalisation was, since the 1990 s, that of more flexibility and less state intervention. It seems now, in the 2012 meeting, that Klaus Schwab wants to become free of the spirits which Davos had also called up, when surprisingly asserting that the capitalist system "in today's form" is not suitable for the world anymore and, as a consequence, demands more (finance) market regulation. ${ }^{46}$

For the future Klaus Schwab, the "Duke of Davos"47, can point to the fact that official US government reports in a scenario about the world in 2020 describe a "Davos world" as a positive example of conflict resolution when "not only governments but all the stakeholders of global society work together in flexible networks to address the challenges present on the global agenda." ${ }^{48}$ After all, the EMF cannot be characterised purely as a lobbying group or association representing particular interests; the vast range of approaches and interests represented has just been too large. It can actually be seen as both a para-diplomatic platform and a form of foreign policy representing non-governmental campaigns. "To cope with structural changes, genuine top secret executives must act as politicians that is to say as a foreign affairs and not as a domestic affairs politician", this being a statement by Schwab in a newspaper article in $1975.4^{49}$ From this perspective we are only one step away from the concept of a global corporate citizenship, whereby a company is active in flexible networks of a global society and is itself a responsible stakeholder, along with governments and agencies from civil society. .0

46 Quoted in Hannes Koch, "Kapitalismus renovieren. Weltwirtschaftsforum von Davos" in Die Tageszeitung, 24.1.2012.

47 Carlyle Adler, "Duke of Davos" in Fortune International, 161, 2, 2010, p. 9.

48 Klaus Schwab, "Global Corporate Citizenship" in Foreign Affairs, 87, 2008, pp. 107-118.

49 Idem, "Der Unternehmenspolitiker" in Neue Zïrcher Zeitung, 29.10.1975, quoted ibid., p. 22.

50 Idem, "Global Corporate Citizenship" in Foreign Affairs, 87, 2008, pp. 107-118. 


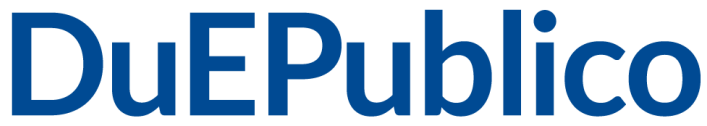

Duisburg-Essen Publications online offen im Denken

Ub $\begin{aligned} & \text { universitäts } \\ & \text { bibliothek }\end{aligned}$

Dieser Text wird über DuEPublico, dem Dokumenten- und Publikationsserver der Universität Duisburg-Essen, zur Verfügung gestellt. Die hier veröffentlichte Version der EPublikation kann von einer eventuell ebenfalls veröffentlichten Verlagsversion abweichen.

DOI: $\quad 10.5771 / 9783845254272 \_343$

URN: urn:nbn:de:hbz:464-20201201-164415-9

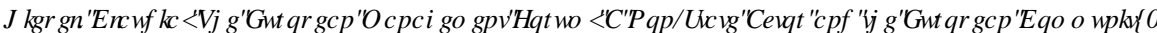

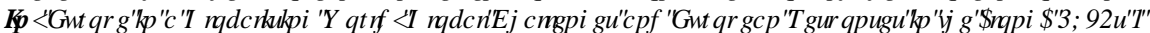

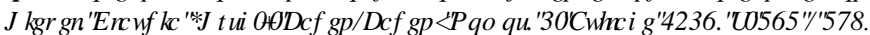

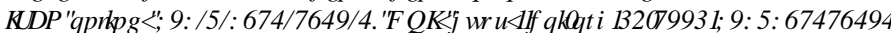

Alle Rechte vorbehalten. 